\title{
Introduction: redefining security in the Middle East
}

\author{
Tami Amanda Jacoby and Brent E. Sasley
}

I

N ITS FORMATIVE stages, the study of the theory and practice of security in all the world's regional subsystems, including that of the Middle East, was defined primarily by the logic of superpower rivalry. For over five decades, the Cold War security agenda was distinguished by the principal strategic balance, that of a structure of bipolarity, between the United States (US) and the Soviet Union (USSR). It also served as the core framework of analysis. In that respect, the 'core' was prioritized, both analytically and politically, over what were considered local or regional disputes raging in an area broadly defined as the 'Third World', now more widely known as the developing world. The latter category was considered theoretically insignificant insofar as conflict in the 'periphery' did not escalate to the point of threatening superpower relations and international stability in the core. For this reason, conflicts in the developing world, whether as proxy wars, internationalized civil conflicts or disputes local in character, were considered either as secondary or superfluous to the international system as a whole.

This exclusion of the developing world from mainstream analysis in international relations (IR) was based on a particular understanding of 'the politcal' in international affairs. Structures representing significant political authority were rendered equivalent to the state system, the military - industrial complex, inter-state war and the diplomatic arena. In particular, the international system and its component parts were defined, for the most part, by the nation state as it developed historically in Europe and was institutionalized through the hegemony of academic and policy-oriented elites in the United States in the postSecond World War era. These Eurocentric and, later, American hegemonic origins were developed as a field of study by, first, realist (Morgenthau, 1973; Carr, 1964) and, later, neorealist (Walt, 1987; Waltz, 1979) scholars who occpied the dominant schools of thought in the field of international relations. According to the realist worldview, security is defined as the protection of the boundaries of a nation state from external military threat with a key focus on 
the threat of conventional warfare, plus nuclear weapons proliferation and superpower rivalries. The idea that superpower nuclear deterrence was a stabilizing function of the international system during the Cold War rendered developing world conflicts invisible insofar as their forms, use of armaments and actors did not fit the established paradigm.

However, the United States and the Soviet Union no longer vie with each other for dominance in the developing world, including their Middle East client states. Although the United States still seeks to maintain influence in that region, the Middle East conflict, as it has been traditionally defined, is 'over' (Thomas, 1999: 278). In other words, inter-state war backed by proxy rivals no longer takes place. This change does not suggest that inter-state conflict in the Middle East can no longer occur - that would be to neglect historical and current realities. However, because of the shift in the international system, inter-state violence is no longer the predominant type of security concern. Other forms of conflict in the Middle East are proliferating at an unprecedented rate, with local and international implications, which cannot be understood using traditional variables.

As a result, it is essential to conceptualize these new conflicts using levels of analysis and conceptual frameworks that are fundamentally different from the conventional realist-neorealist perspective. Including the developing world as a central unit of analysis, or what Amitav Acharya (1997) has termed 'the periphery as the core', significantly alters the process of theorizing the boundaries of the subfield and its principal units of analysis. This type of thinking is essential for exploring issues of security in the Middle East as both dependent and independent variables with respect to the post-Cold War international arena.

Since the end of the Cold War, along with the disintegration of much of its rules, power relations and paradigms, the field of security studies has faced a serious challenge, with input from scholars positioned variously in the areas of Marxism-neomarxism, historical materialism, feminism, environmentalism, postcolonialism and postmodernism. This dissident trend, a broad canvas referred to as 'critical security studies', has shed light on some of the emerging patterns of conflict that have dramatically altered both the contours of security and the possibilities for conflict resolution in the post-Cold War era. The task of revisiting the subject of security has involved a broad range of issues with respect to the state and its function as a protection system and a collective identity structure, and has raised questions of an epistemological and ontological nature, as well as other levels of analysis between the local and the global. By challenging the unified, abstract and ethnocentric bias of mainstream security studies and its realist-neorealist paradigm, critical scholars have opened up space for new understandings of conflict and security in nonWestern regions. In particular, the issues they have raised are directly relevant 


\section{Introduction}

to the Middle East, itself a pivotal regional subsystem in world politics and what Bassam Tibi has referred to as 'a mirror of its changes' (1998b: 216).

This volume seeks to draw from current developments in critical security studies in order to establish a new framework of inquiry for security in the Middle East. The Middle East has always been considered a region of global strategic significance, situated at a crossroads between the continents of Europe, Africa and Asia, bordering the eastern Mediterranean Sea, and site of the world's largest deposit of oil. However, analysis of Middle East security in the current era has been imprisoned in old concepts and outdated paradigms, transplanted from elsewhere, that do not register both the consequence and complexity of conflict in that region. The goal of redefining security in the Middle East is not only to better understand events and processes in that particular geographical area, but to help shed light on other, hitherto marginalized, spaces throughout the world (both within the West and elsewhere) that have been excluded from mainstream analysis. Moreover, our intention is not simply to transport concepts and debates emanating from mainstream IR to the Middle Eastern context, but to capture the complex interface of global and local dialogues as they pertain to the changing circumstances and indigenous understandings of conflict in this region. Our focus is squarely on the Arab-Israeli context in general, and the Palestinian-Israeli context in particular, as these conflicts are yet to be resolved and form the most intractable core of geopolitical relations, issues and transformations in the region as a whole.

\section{Traditional security studies in the Middle East}

Until the 1990s, strategic studies of the Middle East have been particularly opposed to the notion of 'redefining security'. Even during the last decade, the literature on this subject has remained small. In comparison to Western regions and states where, it is argued, liberal capitalist democracies do not go to war, especially with each other (Mueller, 1990; Doyle, 1986), the Middle East remains an area in which protracted militarized, armed conditions of conflict are staples of the political process. For that reason, the study of international politics in the Middle East has been characterized as the study of inter-state war. As a result, much of the literature on the Middle East has focused on the chronology of the Arab-Israeli wars of 1948, 1956, 1967, 1973, the 1982 Israeli invasion of Lebanon and the 1991 Gulf War. These wars have been used as benchmarks in the history of the region (see, for example, Bickerton and Klausner, 1991) and as signifiers of collective identities frameworks and loyalties (see, for example, Karsh, 1996; Sicker, 1989).

These methods of studying Middle Eastern politics are predicated upon the Cold War realist logic described above. Superpower rivalry over the region did 
not begin in earnest until the 1960s, when American support for Israel began to increase significantly. ${ }^{1}$ At that time, the Soviet Union began actively supporting the more radical Arab states opposed to Israel and Western, especially American, involvement in the region, encouraging opposition to Washington and its policies. While American policy centred on defending Israel against threats to its state security and ensuring continued, safe and reliable access to Persian Gulf oil supplies, Soviet goals were to prevent the use of the region as a staging area by the West in an attack on the Soviet Union's 'soft underbelly' of the Caucasus and Central Asia, and to extend Communist influence both in the Middle East as a whole and within each country. Many analysts interpreted the Arab-Israeli wars of 1967 and 1973 as proxy wars between the USSR and the US on account of the use by Israelis and Arabs of their patrons' weapons in battle and their attempt to advance the roles of their benefactors in the area.

The imposition of superpower competition on the Middle East (Ovendale, 1992; Bar-Simon-Tov, 1987) had the effect of bringing the focus of conventional security studies to the region. However, events within the region itself contributed to the spread of realist ideas of conflict and security. On the Arab side, leaders and regimes sought to unite their discontented and/or disparate ethnic, religious and linguistic communities under a patriotic banner defending the country (see, for instance, Hiro, 1989). This type of unity required emphasis on an external enemy to deflect attention away from internal concerns. On that basis, domestic demands could be shunted aside in the name both of national security interests and of regaining, by force, Arab lands lost to Israel in 1967 (el-Shazly, 1986). This process had the effect of generating political legitimacy for otherwise undemocratic and/or illegitimate rulers (Sela, 1998; Safran, 1969). Israel, for its part, felt itself beset by hostile countries on all sides, and thus was concerned primarily with defence matters by virtue of that geographical circumstance (Safran, 1978). For this reason, Israeli resources were directed towards securing the country from external threat, the most prominent and serious concern. Partly as a result of these concerns, tensions and disputes over borders - an important aspect of traditional security concerns - became an issue of paramount importance between states. Israel's relations with Syria, Lebanon, Jordan (until 1994) and Egypt (until 1979) were partly conditional on the resolution of where the border between the countries would fall. A 1975 Brookings Institution report on the prospects of peace in the region reiterated this focus on sovereignty, territorial integrity and secure borders - all realist notions - while neglecting other facets of security. Security studies of the Middle East seemed, therefore, to be a natural method of understanding state behaviour.

Since much of the analyses of security studies took as their empirical reference the more advanced industrial countries of the world (including 
democracies and also non-democracies), the end of the Cold War brought to light the inability of such analyses to properly address security concerns of non-developed countries. Scholars began to point out that although war and conflict seemed to be disappearing from the developed world, they remained a constant in the developing world, including primarily Africa, parts of Asia, and the Middle East (Holsti, 1996). Moreover, conflict took place not only between the traditional referent points (i.e. states), but within states themselves, between various communal linguistic, religious or ethnic groups, or between the state itself and individuals or societal groups (Holsti, 1998). The restraint imposed by the Cold War competition, which dampened national and subnational rivalries in favour of aligning with and following the lead of one camp or another, was gone. There was nothing in its place. Instead, those groups whose particular interests had hitherto been repressed in the name of Cold War politics realized they could freely pursue their own interests in ways that did not coincide with the inter-state system.

Undoubtedly, one cannot underestimate the influence of these events and theories on the politics of the region. However, since the end of the Cold War, the types of conflict characterizing the Middle East have undergone a profound transformation, requiring new ways of thinking about threat, danger and protection. The challenge of redefining Middle East security is both theoretical and political. Theoretically, new concepts of security in the Middle East have much to offer critical analysis insofar as changes in that region provoke new understandings of trends of conflict and conflict resolution in a globalizing world. Politically, new concepts of security challenge the status quo in the region and offer alternative visions of the Middle East that are more peaceful and optimistic than those of today.

Two of the most significant political events that have served to revise thinking about security in the Middle East are the Palestinian intifada from 1987 to 1993, and the start of the Middle East peace process since 1991. Both events altered the geopolitical landscape of the Middle East in profound and unlimited ways, and have provoked scholars and practitioners alike to devise new methods of conflict and conflict resolution in the region.

The Palestinian intifada $a^{2}$ began in $1987^{3}$ as a case of an internal conflict that was irresolvable by military means. Since the 1967 War, Israeli occupation of the West Bank and the Gaza Strip, although condemned by the international community, has sustained itself with little internal resistance. The uprising was clearly a popular insurrection that defied the conventional rules of war in which soldiers fight soldiers on the battlefield. Instead, the Israeli military faced an 'enemy', composed largely of Palestinian women and youth (shabab), that protested within civilian areas, neighbourhoods and the private sphere, spaces that are conventionally understood to lie outside the range of military combat. 
Moreover, the discourse of 'enlightened occupation' that had sustained the legitimacy in Israeli public opinion of Israeli control over the West Bank and Gaza since 1967 was exposed during the intifada as oppressive and unjust. Additionally, the question arose about the degree to which military occupation served the interests of Israeli security in the first place. Many analysts, including the majority of the general staff of the Israel Defence Forces (IDF) (quoted in Thomas, 1999: 252) stated that territory did not necessarily hold strategic value, and could even, as this case demonstrated, become a burden to the occupying society and a risk to Israeli security. Indeed, the increasingly oppressive nature of the Israeli occupation served only to fuel a cycle of violence constituted by Israeli belligerence followed by Palestinian anger, discontent and radicalization. Bassam Tibi suggests that this new pattern of 'irregular warfare' problematizes the civilian-military distinction and the role of the military-industrial complex in conflict resolution in post-Cold War conditions (Tibi, 1998b: 215).

The Middle East peace process ${ }^{4}$ (MEPP) was an additional factor in problematizing the military-strategic concept of security in the Middle East. The MEPP fundamentally altered the structures and symbols of security and statehood in the region, rendering the military option less popular, at least in the view of the international community. A more propitious climate for diplomatic negotiations in the 1990s resulted from a series of international pressures and realignments. Along with the intifada, popular opinion in other Middle Eastern societies expressed an increasing dissatisfaction with the human cost of militarized conflict.

The Madrid Peace Conference in 1991 was the first instance in which parties to the Arab-Israeli conflict engaged in direct bargaining at the negotiating table. Madrid set the stage for a series of bilateral and multilateral negotiations that would reflect renewed desire for peace in the region and recognition that the realities of the international system that had contributed to the continuation of inter-state hostilities were no longer part of the predominant framework. In addition to the momentum established at the Madrid conference, a Labour Government, traditionally seen as more willing to engage in peace negotiations, came to power in Israel in 1992 (the first since 1977). That Government entered into secret talks with Palestinian Liberation Organization (PLO) officials in Oslo, Norway. The Oslo process, as it has come to be known, had the effect of bypassing the very public Madrid agendas and allowed for concrete efforts and results between the Palestinian and Israeli sides without the glare of publicity and attention or the opportunity for hard-liners opposed to such negotiations to derail them. While the secrecy of these talks raised questions about the democratic nature of the peace process, they did manage to produce a series of agreements, namely the Oslo Accord of 13 August 1993, 
the Declaration of Principles signed on the White House lawn on 13 September 1993, the Oslo II Accord of 28 September 1995, and the Wye River landfor-peace Accords of 23 October 1998.

These agreements have resulted in modest advances in Middle East peace. However, at the same time, the different parties to negotiations have become embroiled in the most intractable final status issues such as: the exact contours of Palestinian statehood; borders; Palestinian refugees; Jewish settlements; and Jerusalem. In terms of the broader Israeli-Arab peace negotiations, the talks have continually broken down over Israel's position in southern Lebanon (until the Israeli withdrawal in May 2000), Israeli-Syrian relations, and wider issues related to the positions of other regional actors. That these issues are ongoing reveals the precarious nature of the peace process as a whole. The assassination of Prime Minister Rabin by an Israeli right-wing extremist in 1995, the election of right-wing governments in Israel in 1996 and 2001, and the outbreak of the second intifada since September 2000, further exemplify the unstable nature of negotiations, and perhaps, more importantly, the flawed understandings of peace and security that underpinned the Oslo process. Recently, rejectionist and radical fundamentalist movements have mobilized on both sides, and have increased their popularity as negotiations at the leadership level failed to bear fruit.

As a result of the peace process, and the debates it has engendered, increasing political polarization and radicalization has occurred, both between state and society, and between different social groups. On the one hand, there has been increasing intransigence and potential for violence among a diverse multitude of regional interventions, actors and cleavages. On the other hand, the peace process has challenged conventional taboos about Arab-Israeli relations and has placed on the agenda a variety of new security issues related to environmental issues, economic development, democratization and internal cleavages based on political, social, religious, ethnic and other identities. These unresolved issues resulting from the Palestinian intifada and the MEPP demonstrate the futility of conventional thinking about security from a statist-military perspective. The need for new and more inclusive security frameworks has become readily apparent.

A multi-dimensional approach to security in the Middle East does not seek to ignore traditional military security issues, such as the proliferation of weapons of mass destruction and ballistic missile technology, arms purchases, counter-terrorism, traditional balance of power calculations, interaction with external influences, borders and territorial disputes, and inter-state wars. However, a deepening of the subject matter would involve consideration of the non-traditional variables that have arisen as security issues in Middle Eastern politics. Critical security has served as a prominent point of reference for new 
approaches to conflict in all geographical regions, with particular implications for redefining security in the Middle East.

\section{Critical security studies - a source for revision}

Critical security studies is a body of nascent experimental and exploratory knowledge that, as Richard Ashley and R. B. J. Walker argue, serves to 'transgress arbitrary limits, open up hitherto closed off connections, and enable the construction and circulation of new ways of knowing and doing politics' (Ashley and Walker, 1990: 264). Despite the considerable diversity of critical voices in IR, a commonality lies in their desire to pry open 'thinking space' (George and Campbell, 1990: 269), in an otherwise unyielding paradigm that focuses, almost exclusively, on state sovereignty and its underlying configuration of authority and political identity. The challenge of critical security is to reframe some of the most basic epistemological, ontological and political orthodoxies of the field and include, according to Christine Sylvestor, 'activities we do not often study as IR, and people we think of having no place there' (1994: 193). This type of thinking is essential for the Middle East, a region where fundamental changes emanating from both international and local politics refocus the gaze on new actors, new concerns and new areas of conflict and conflict resolution.

Critical security would help to transform the meaning of and possibilities for security in the Middle East in two fundamental ways. First, it seeks to broaden the field to include the new issues, challenges, actors, relations and units of analysis that have arisen in the post-Cold War era. New threats and dangers in the Middle East are articulated in relation to environmental risk, terrorism, fundamentalist movements, structural violence, neo-colonialism, migration and refugees, economic scarcity, ethnic and racial conflict, domestic abuse/ violence against women, and political and human rights. These issues both exceed and render problematic the limited boundaries of the field as they take place across and beyond state boundaries and cannot be resolved by any particular state structure on its own.

Second, and perhaps more importantly, critical security attempts to deepen the field by considering epistemological and ontological issues, for example, the relationship between security and its underlying claims to knowledge and images of reality. Theorizing security at this metatheoretical level opens up practical questions about identity, prospects for emancipation, change, justice, political authority and the character of the human sciences. In this way, security can be analysed not as a transparent reflection of 'national interest' (broadly defined) or citizenship rights and duties, but as a discursive site of contestation. As Simon Dalby (1997) argues, critical security is 'an essentially contested concept', as well as a repository of other meanings and affiliations. 
From a critical perspective, security can be regarded as a site for the transmission of values, the legitimization of claims to knowledge, and the production and reproduction of collective identity formations. If the origins of fear and perceptions of threat fluctuate along socio-temporal lines, then the agent and nature of security cannot simply be linked to the state as an abstract entity, but must be regarded as both historically variable and contextually specific (Krause and Williams, 1997). In that respect, the determinants of security, as a theory and as a practice, relate to cultural, religious, ${ }^{5}$ national, social, economic, and familial and other factors. Barry Buzan (1983: 363) reinforces this point in stating that 'attempts to treat security as if it was confined to any single level or any single sector invite serious distortions of understanding'. By broadening and deepening its agenda, critical security opens a vast and more inclusive terrain for the reposing of questions, long considered resolved in the field, about what it means to be 'secure' in the Middle East.

To deepen the field, critical security borrows substantially from the sociology of science debates in such diverse disciplines as sociology, anthropology, psychology, cultural studies and women's studies. These areas have undergone profound transformations in recent years as a result of the influence of New Left thinking (with residual elements of Hegelian Marxism) since the 1960s, feminist theory, constructivism, and the poststructuralist turn since the 1980s.

Influenced to a great extent by the works of German social theorist Juergen Habermas and Italian Marxist writer Antonio Gramsci, critical theory acknowledges the political interests driving theory itself and the unity of empirical research with human emancipation. The concept of emancipation has featured in Kenneth Booth's work on security in which he proposes that security be co-terminous with 'the freeing of people (as individuals and groups) from those physical and human constraints which stop them from carrying out what they would freely choose to do' (1991: 319). While some are critical of this broad definition of security because of its perceived lack of conceptual coherence (see Ayoob, 1997), a more inclusive study of security would take seriously the diversity of peoples and the basic, and the more elaborate, means by which humans attain fulfilment and happiness. The orientation of critical security as a peoplecentred, rather than state-centred, approach renders it necessary to focus on the relationship between theory and political praxis.

The constructivist school of thought in IR (Wendt, 1999) has made a significant contribution to understanding and theorizing the security of people rather than of states. Constructivism's two most significant contributions to redefining security are in its more interpretative approach, which focuses on ideas, norms and intersubjective meanings, and also on its capacity to study security from the perspective of the participant and his/her perceptions of threat and danger based on his/her relationships and affiliations. 
Taking this interpretative focus a step further, postmodernist perspectives in IR find evidence of the power to define security in identity construction and language (Madar, 2000). Radical forms of postmodernism preclude the existence of a unified identity in any form. However, postmodern deconstruction of security 'texts' have been useful in demonstrating ways in which national security writing is used to justify defence of the state through the production of domestic consensus and repressive hierarchies at home, while perpetuating conflict abroad against the overseas enemy - broadly defined (Madar, 2000: 82). Postmodern analysis in critical security studies has considered the role of language in determining security agendas. For example, Buzan, Waever and de Wilde analyse security in terms of a 'speech act' or what they call 'securitization', to denote the process in which an existential threat and special measures designed to meet that threat are created by uttering particular discourses (Buzan, Waever and de Wilde, 1998).

Influenced to a large extent by Lacan's definition of 'the symbolic order' (1977) and Foucault's notion of discourse as a 'social practice' (1972), critical security studies scholars have demonstrated that security is itself a discourse, or 'text', that can be read and interpreted in a variety of ways. Those who wield power and command resources to both define and combat a particular threat have the greater capacity to implement dominant security discourses and thus set the policy agenda. In other words, issues are 'securitized' by those in power, despite the fact that threats are tentatively constituted and subject to interpretation by individuals and groups within a particular socio-historical conjunction.

The intervening influence of language in critical security studies demonstrates that representation in any context, or the relationship between the object (threat) of security and knowledge (fear) about it cannot be neutral. As a representational practice, security has been associated with various worldviews, cultures, civilizational consciousnesses, theologies and lifeways. From a critical perspective, these forms of representation are treated as neither monolithic nor as aggregate of individual beliefs. Instead, they form an overall picture of mediating claims over the social construction of threat and danger based on various interpretations of indigenous laws, popular customs, social taboos, material circumstances and external influences.

Scholars studying the developing world have contributed a significant set of culturally specific variables to the study of security. Security studies in these regions demonstrate that the predominant diplomatic-strategic conception of security as the physical protection of nation states from external military threats is Eurocentric and inapplicable to many of the quandaries of insecurity in developing and/or non-Western societies. Developing-world security quandaries result from differential patterns of state formation that were often constructed out of colonial power. The colonial element affected elite recruitment and regime establishment and maintenance (Ayoob, 1983-84). In 
particular, primary sources of developing-world insecurity are linked to problems of legitimacy, resulting from a lack of congruence between a state's territorial boundaries and its underlying social composition. This pattern of state development has resulted in the protracted social and civil/ethnic conflicts of today (Azar and Moon, 1984).

Popular dissent in developing societies amplifies the contradictions between regime self-preservation (regime security) and social welfare (human security). Developing-world scholars have established the contextual and historical evidence that states often constitute a greater threat to the lives and well-being of their citizens (lack of democracy) than does the threat from external enemies (war). Widespread poverty, underdevelopment, ecological scarcity and overpopulation compound the problem of internal security in the Middle East. These issues are non-military in nature and cannot be contained within the state system or resolved by military action (Azar and Moon, 1984). A focus on context and historical specificity further develops the study of security in the Middle East, itself a crossroads between the developed and the developing world. As such, Middle East security exhibits characteristics from both worlds, and in many ways serves as a meeting point between Western and non-Western dialogues.

Feminist scholars have also made a significant contribution to critical security, articulating new theoretical and practical implications of danger and protection. The field of IR as a whole has been particularly hostile to feminist interventions. This exclusion is a result in part of the nature of its subject matter, i.e. war, security and the state system, spaces that have historically been occupied almost exclusively by men. Feminist scholars have offered strong critiques of the prevailing orthodoxy by pointing out that the depiction of states as rational-unitary actors seeking national security prioritizes militarystrategic issues (Sylvestor, 1994; Peterson, 1992; Tickner, 1992; Enloe, 1989; Elshtain, 1987). The construct of the male citizen-warrior predominates in accounts of state making and its protection systems in relation to the exclusion of women from the capacity to control the conditions of their own protection. This dichotomy of protector versus protected represents a prominent, albeit gendered, structure in IR that reinforces the authority of men and states over women, who have traditionally been defined as vulnerable and in need of protection. By establishing the male citizen-warrior as the primary model of citizenship (via his representation of the state's legitimate monopoly over the means of coercion), men become the more significant foundation for analysing strategic studies. As a result, the most pervasive forms of structural and direct physical violence in society by men against women, i.e. domestic violence and sexual assault/rape, are rendered invisible in dominant accounts (Roberts, 1984: 196). On account of the dominant position of the military in the Middle Eastern region, issues of gender violence and the connection between gender 
and security have only recently begun to surface in public discourses, largely because of the politics of women's resistance and the debates about women's right to fight.

As a whole, this broad terrain of critical security scholars has opened up the field of security studies to new thinking. The context-specific mode of analysis holds important implications for the theory and practice of security in the Middle East. The contributors to this volume draw in one way or another from the cache of tools given by critical security scholarship outlined above. In so doing, they further the debate about critical security studies through different case studies, methodologies and contextual specificities associated with the Middle East.

\section{Implications for security studies of the Middle East}

While the development of critical security studies has taken place largely outside the Middle Eastern context, many of its concepts, theories, debates and practices are significant for redefining security in the Middle East. This volume employs critical security studies tools to reframe political, social, gender and environmental issues as security issues.

First, the book considers security in relation to the political sector in terms of processes of democratization in the region and demands of new groups for wider and more meaningful access to political decision making. The notion of political security would address the accountability of governments and public liberties and freedoms, including possibilities for dissent. Leaders in the Middle East have demonstrated clearly an inability to either discern or to accept the desires for change taking place at the popular level and to execute appropriate policy initiatives. By deflecting energies away from domestic issues, political leaders have obstructed the development of a more robust civil society and the involvement of social movements and protest groups with the political process.

Second, the book explores security in relation to the construction of social groups and collective identities. The Middle East consists of a wide range of ethnic, religious, linguistic, ideological and cultural groups that have, for the most part, been collected together in state organizations with little regard for their differences and historical enmities. These reciprocal misgivings and traditional contrarieties have problematized attempts at co-operation in the name of higher interests affecting all sectors and have resulted in discrimination against minorities and political persecutions. The social dimension of security must include issues related to cultural integration, confidence-building measures, inter-ethnic dialogue, people-to-people contacts, religious and other collective identifications, discourses and perceptions based on class, gender, religion, ethnicity, nationality, and so on. 
Finally, the book examines the significance of ecopolitics in security agendas in the Middle East. Essential natural resources such as water, food, energy and dependence on foreign suppliers are environmental issues that affect not only Middle Eastern national security agendas but human security agendas worldwide. However, by contrast to concerns about macro-environmental issues, such as global warming, prevalent in studies of ecopolitics in the West, the Middle East is plagued by more micro-environmental concerns that affect people's immediate livelihoods and chances for survival. Within this geographical unit, there are shared surface and subsurface water basins, shared seas and bodies of water, and flora, fauna and other natural resources. Conflict is closely related to access to clean water and its distribution. Recent developments have indicated that the age of the oil war may be supplanted by that of the 'war for water', the scarcest resource in the area (Anderson, Siebert and Wagner, 2001: 256). In addition, the Arab-Israeli conflict has brought about environmental questions related to land confiscation, waste management, agriculture, deforestation and air pollution.

The areas of political, social, religious, cultural and environmental security, are all subject to contestation, power relations and collective affiliations. Moreover, these areas have changed dramatically since the start of the Middle East peace process. However, they have been complicated by several factors in the Middle East, and these need to be addressed in terms of a broad security framework.

To summarize, the commitment of this volume is twofold. First, the collaborators seek in various ways to challenge the orthodoxy of security thinking by employing different critical security concepts in relation to the Arab-Israeli context. It is not the purpose of this book to deny the importance of security threats grounded in military or strategic concerns. It is neither assumed that such security concerns should be subsumed beneath non-military facets, nor asserted that the state is no longer an actor of significance: studies based on those facets, as well as on the future of military security in the region, are important for both practical and theoretical reasons. Rather, the book maintains that non-military, non-realist, notions of security are also notable aspects of security studies. There is a small, but growing, literature on this subject, ${ }^{6}$ but few volumes are comprehensive in scope.

Second, the collaborators seek to broaden and deepen the definition of security in the Middle East as a means by which to develop alternative approaches to security that take into consideration the range of issues tackled in this volume. The contributors come from a variety of different social, national, religious, ethnic, and racial backgrounds. The differing epistemologies and political purposes reflected here disavow any common goal on the part of the contributors to develop a single alternative approach to security in the Middle East. That would be counterproductive considering the diversity of identity 
expressed in this project. Instead, the goal is to promote a more inclusive dialogue within the framework of a 'critical project' on the meaning and practice of security in the Middle East. This intervention is regarded as part of an emerging and ongoing debate about security in the world in general, and in the Middle East in particular. The Middle Eastern component provides a useful laboratory for raising scholarly and practical issues, but also for promoting peace in Middle Eastern security agendas in a way that includes the diversity of peoples, identities, interests and shared hopes for a better future. In that sense, this study is designed as a heuristic tool for furthering our theoretical understanding of concepts of security, which can help provide more effective models of conflict resolution.

\section{Breakdown of chapters}

The first four chapters of the book establish a theoretical context for redefining security in the Middle East by considering a range of concepts, debates and theories that have traditionally been absent from the field. This shift in analysis from national security to human security (the security of groups and individuals) reflects the transformations of the post-Cold War era by combining military with non-military concerns such as environmental damage, social unrest (refugees, rebellion and revolution), economic mismanagement, cultural conflict, gender inequity and radical fundamentalism. The Middle East is an excellent laboratory in which to investigate these transitions, having acquired new significance in the global arena as an area of concern in itself, yet one still undergoing conditions of protracted conflict.

In chapter 2, Lenore Martin provides an analytical model for redefining national security as a theory and as a practice in the post-Cold War era. This model defines 'national security' as the ability of a state to deter or counter threats to its three components: territory; society; and regime. By way of contrast to realist IR theory, developing-world theorists have proposed a different set of variables to explain the unique challenges facing developing states, where threats emanate from internal, transnational and external sources. Martin proposes a set of five interacting variables with which to analyse security: military capability; political legitimacy; ethnic and religious tolerance; natural resources; and economic capabilities. The explanatory power of the paradigm derives from the integration of these variables, with particular reference to the relationship of Israel and the Palestinian National Authority.

In chapter 3, Jonathan B. Isacoff adopts a historical constructivist perspective for revisiting the concept of security. The main argument is that the character of Arab-Israeli relations can be measured in large part by the evolution of Israeli foreign policy debate from the 1950s to the 1990s, in particular, 
the competition within Israeli politics and society between the opposing doctrines of militarism and moderation. This foreign policy lens on the Arab-Israeli conflict suggests that a fully consolidated peace agreement will follow only the waning of militarism and the waxing of moderation as the dominant Israeli doctrine guiding both Israel's position in the peace process and the establishing of national and personal security within Israel.

Chapter 4, by Bassam Tibi, undertakes a dialogue between Islam and Islamism as a means to broaden the terrain on which conflict resolution and post-bipolar security in the Middle East is to be understood. He argues that political Islam, as the prominent (rejectionist) front against the official peace process and Western influence in the region, has gained the capacity to destabilize, create disorder and participate in the realm of political conflict. However, he points to fundamental differences between Islam as a spiritual faith and Islamism as a politicized form of religion with tendencies to neo-absolutism and violence. This chapter explores fundamental issues related to Islamophobia and the West, the relationship between Islam and democracy, and circumstances for groups and parties to gain political power and effect social change through indigenous tools and symbols. The intricate distinctions are presented between Islam, political Islam, other forms of religious fundamentalism, and terrorism in relation to the Arab-Israeli conflict, the Mediterranean region and the diaspora.

In chapters 5-8 the emphasis is on issues related to gender, environmental, religious, political and societal security. In chapter 5 Tami Amanda Jacoby rethinks the relationship between gender and security in the Middle East, with a particular focus on the politics of women's resistance in Israel. The Middle East peace process between Israel and the Palestinians since 1991 has problematized struggles for gender equality. First, the predominant understanding of security at the diplomatic level has been become a matter of agreements among states, promoting a limited cessation of hostilities backed by armed force. Second, the focus on diplomatic negotiation not only increased the status of military leaders but usurped the momentum of popular struggle during the occupation era and the Palestinian uprising when women were prominent at the grassroots level. Women have responded in two major ways to the gender boundaries underlying diplomacy, national security and state building in Israel. On the one hand, women have struggled for equal access to the right to fight in the Israeli military. On the other, women have struggled for a negotiated settlement to the conflict within the context of the Israeli women's peace movement. These divergent roles occupied by women in the peace process era hold different implications for an understanding of gender and national security in Israel.

Jeffrey Sosland introduces, in chapter 6, the notion of environmental security, suggesting that security studies scholars have long objected to the inclusion 
of the environment in their research agenda. However, regions such as the Arab-Israeli one suffer from seasonal drought, if not continual water crises. As a result, distribution and discrimination are highly sensitive questions that become viewed by the affected riparians as threats to national security. Traditional concepts such as deterrence and verification, employed in treatments of other security issues, fall short of providing peaceful solutions to environmental insecurity. This chapter suggests that violent conflicts in the Middle East often result from resource scarcity. It provides an empirical case study of water scarcity between Israel and the Palestinian areas of the West Bank and the Gaza Strip prior to, and as a factor in, the outbreak of the Palestinian uprising against Israeli occupation (intifada). Conclusions are then drawn for the present Middle East peace process.

In chapter 7, Thomas J. Butko examines the role of political Islam in the Middle East peace process through a case study of Hamas, the Islamic resistance movement, in the West Bank and Gaza, one of the most significant Palestinian forces opposed to the peace process and thus the only viable, albeit problematic, alternative to the PLO-PNA's hegemony over Palestinian society. This case of Hamas is employed to demonstrate that, in examining issues of security in the Middle East, it is important to consider the politicization of religion as a critical discourse positioned against the state system and an important influence over the development of national security agendas in the Middle East. Extremists and rejectionists on either side seek to exploit the weaknesses inherent in the security apparatus to further their own interests. He argues that it is only by including previously excluded groups and their constituencies, such as Islamist movements, and considering the penetration of politics by their belief systems that a concrete and durable peace can be established in the Middle East.

Brent E. Sasley investigates the effects of political liberalization on security in the Middle East. The growth of civil society in the Middle East has occurred in tandem with underlying processes of political and economic liberalization. These changes, examined in chapter 8 , have placed increasing demands on the state. Previously, demands for social security and political rights were either ignored or easily placated by focusing attention on foreign policy agendas, particularly the Arab-Israeli conflict. However, and particularly since the start of the Middle East peace process, the pressure to democratize has led governing elites to become concerned for their own position and safety, thus turning their attention from external enemies toward (perceived) internal enemies. This effect of political liberalization not only calls into question the referent object of security (i.e. the distinction between the security of rulers/elites, states and societies), but contributes to debate about threat perception, the appropriate agent responsible for policy development vis-à-vis national security and a better understanding of policy options that include the security and protection of the diversity of actors in the region. 


\section{Introduction}

\section{NOTES}

1 However, alignment with the moderate Arab states of the region, particularly in the Persian Gulf, had been a plank of US foreign policy since the late 1940s.

2 The Palestinian intifada (literally, 'shaking off') was ignited on 8 December 1987 by an auto accident in Gaza that sparked rioting, first in Gaza and then throughout the West Bank. For more on the Palestinian intifada, see Lockman and Benin, 1989.

3 The second intifada started in September 2000, and is still raging at the time of writing.

4 For more on the Middle East peace process see Peleg, 1998.

5 For further discussion of the role of political Islam and the state see Tibi, 1998a.

6 For an examination of various facets of national security in the Arab world, see Korany, Noble and Brynen, 1993 and Martin, 1999. For an exploration of societal security concerns within Israel see Bar-Tal, Jacobson and Klieman, 1998.

\section{REFERENCES}

Acharya, Amitav. (1997), 'The Periphery as the Core: The Third World and Security Studies', in Keith Krause and Michael C. Williams (eds), Critical Security Studies, Minneapolis: University of Minnesota Press, 299-327.

Andersen, Roy R., Robert F. Seibert and Jon G. Wagner. (2001), Politics and Change in the Middle East: Sources of Conflict and Accommodation, Upper Saddle River, NJ: Prentice-Hall.

Ashley, Richard and R. B. J. Walker. (1990), 'Introduction: Speaking the Language of Exile: Dissident Thought in International Relations', International Studies Quarterly 34, 259-68.

Ayoob, Mohammed. (1997), 'Defining Security: A Subaltern Realist Perspective', in Keith Krause and Michael C. Williams (eds), Critical Security Studies, Minneapolis: University of Minnesota Press, 121-46.

Ayoob, Mohammed. (1983-84), 'Security in the Third World: the Worm About to Turn'?, International Affairs, 60:1 (Winter), 41-51.

Azar, Edward and Chung-in Moon. (1984), 'Third World National Security: Towards a New Conceptual Framework', International Interactions, 11:2, 103-35.

Bar-Simon-Tov, Yaacov. (1987), Israel, the Superpowers, and the War in the Middle East, New York: Praegar Publishers.

Bar-Tal, Daniel, Dan Jacobson and Aharon Klieman (eds). (1998), Security Concerns: Insights from the Israeli Experience, Greenwich, CT: JAI Press, Inc.

Bickerton, Ian J. and Carla L. Klausner. (1991), A Concise History of the Arab-Israeli Conflict, Englewood Cliffs, NJ: Prentice-Hall, Inc.

Booth, Kenneth. (1991), 'Security and Emancipation', Review of International Studies, 17: 4 (October), 313-26.

Brookings Institution. (1975), Toward Peace in the Middle East: Report of a Study Group, Washington, DC: Brookings Institution.

Buzan, Barry. (1983), People, States and Fear, Chapel Hill: University of North Carolina Press.

Buzan, Barry, Ole Waever and Jaap de Wilde. (1998), Security: A New Framework for Analysis, Boulder, CO: Lynne Rienner Publishers.

Carr, Edward Hallett. (1964), The Twenty Years' Crisis, 1919-1939: An Introduction to the Study of International Relations, 2nd edn, New York: Harper \& Row.

Dalby, Simon. (1997), 'Contesting an Essential Concept: Reading the Dilemmas in Contemporary Security Discourse', in Keith Krause and Michael C. Williams (eds), Critical Security Studies, Minneapolis: University of Minnesota Press, 3-31.

Doyle, Michael W. (1986), 'Kant: Liberalism and World Politics', American Political Science Review, 80: 4 (December), 1151-69. 
Elshtain, Jean Bethke. (1987), Women and War, New York: Basic Books.

Enloe, Cynthia. (1989), Bananas, Beaches, and Bases, Berkeley: University of California Press.

Foucault, Michel. (1972), The Archeology of Knowledge and the Discourse on Language, New York: Pantheon Books.

George, Jim and David Campbell. (1990), 'Patterns of Dissent and the Celebration of Difference: Critical Social Theory and International Relations', International Studies Quarterly, 34, 269-93.

Hiro, Dilip. (1989), The Longest War: The Iran-Iraq Military, London: Grafton.

Holsti, Kalevi J. (1998), 'The Coming Chaos? Armed Conflict in the World's Periphery', in T. V. Paul and John Hall (eds), International Order and the Future of World Politics, Cambridge: Cambridge University Press, 283-310.

Holsti, Kalevi J. (1996), The State, War and the State of War, Cambridge: Cambridge University Press.

Karsh, Efraim (ed.). (1996), Between War and Peace: Dilemmas of Israeli Security, London: Frank Cass \& Co.

Korany, Bahgat, Paul Noble and Rex Brynen (eds). (1993), The Many Faces of National Security in the Arab World, New York: St. Martin's Press.

Krause, Keith and Michael C. Williams. (1997), 'Preface: Toward Critical Security Studies', in Keith Krause and Michael C. Williams (eds), Critical Security Studies, Minneapolis: University of Minnesota Press, vii-xxi.

Lacan, Jacques. (1977), Ecrits: A Selection, translated from the French by Alan Sheridan. London: Tavistock Publications.

Lockman, Zachary and Joel Benin. (1989), Intifada: The Palestinian Uprising Against Israeli Occupation, Toronto: Between the Lines (MERIP).

Madar, Daniel. (2000), Canadian International Relations, Scarborough, ON: Prentice-Hall and Allyn \& Bacon Canada.

Martin, Lenore. (1999), New Frontiers in Middle East Security, New York: St. Martin's Press.

Morgenthau, Hans J. (1973), Politics Among Nations: The Struggle for Power and Peace, 5th edn, New York: Knopf.

Mueller, John E. (1990), Retreat from Doomsday: The Obsolescence of Major War, New York: Basic Books.

Ovendale, Ritchie. (1992), The Origins of the Arab-Israeli Wars, 2nd edn, London: Longman.

Peleg, Ilan. (1998), The Middle East Peace Process: Interdisciplinary Perspectives, Albany: State University of New York Press.

Peterson, V. Spike. (1992), Gendered States: Feminist (Re)Visions of International Relations Theory, Boulder, CO: Lynne Rienner Publishers.

Roberts, Barbara. (1984), "The Death of Machothink: Feminist Research and the Transformation of Peace Studies', Women's Studies International Forum, 7:4, 195-200.

Safran, Nadav. (1978), Israel: The Embattled Ally, Cambridge, MA: Belknap Press.

Safran, Nadav. (1969), From War to War: The Arab-Israeli Confrontation, 1948-1967, New York: Western Publishing Company, Inc.

Saunders, Harold H. (1985), The Other Walls: The Politics of the Arab-Israeli Peace Process, Washington, DC: American Enterprise Institute for Public Policy Research.

Sela, Avraham. (1998), The Decline of the Arab-Israeli Conflict: Middle East Politics and the Quest for Regional Order, Albany: State University of New York Press.

el-Shazly, Saad. (1986), The Arab Military Option, San Francisco: American Mideast Research. Sicker, Martin. (1989), Israel's Quest for Security, New York: Praegar Publishers.

Sylvestor, Christine. (1994), Feminist Theory and International Relations in a Postmodern Era, Cambridge: Cambridge University Press. 


\section{Introduction}

Thomas, Baylis. (1999), How Israel Was Won: A Concise History of the Arab-Israeli Conflict, Boulder, CO: Lexington Books.

Tickner, Ann J. (1992), Gender in International Relations, New York: Columbia University Press.

Tibi, Bassam. (1998a), The Challenge of Fundamentalism: Political Islam and the New World Disorder, Berkeley: University of California Press.

Tibi, Bassam. (1998b), Conflict and War in the Middle East: From Interstate War to New Security, New York: St. Martin's Press.

Walt, Stephen M. (1987), The Origins of Alliances, Ithaca, NY: Cornell University Press.

Waltz, Kenneth N. (1979), Theory of International Politics, Reading, MA: Addison-Wesley Publishing Company.

Wendt, Alexander. (1999), Social Theory of International Politics, Cambridge: Cambridge University Press. 